\title{
The Role of Vitamin D in Disease Activity in Axial Spondyloarthritis
}

Authors:

Geraint Alun Brown, ${ }^{1}$ Elena Nikiphorou ${ }^{2}$

1. Department of Rheumatology, Peterborough City Hospital, North West Anglia NHS Foundation Trust, Peterborough, UK

2. Department of Rheumatology, Kings College Hospital, London, UK

*Correspondence to enikiphorou@gmail.com

Disclosure: $\quad$ The authors have declared no conflicts of interest.

Received: $\quad 16.03 .20$

Accepted: $\quad 05.05 .20$

Keywords: $\quad$ Axial spondyloarthritis (axSpA), disease activity, vitamin D.

Citation: $\quad$ EMJ Rheumatol. 2020;7[1]:118-127.

\section{Abstract}

Axial spondyloarthritis (axSpA) is a chronic inflammatory disease which predominantly involves the axial skeleton and sacroiliac joints. The aetiology remains unknown but is thought to be immune driven. Vitamin $D$ is a focus for research in numerous autoimmune conditions, especially because it is now thought to have an important role in immunoregulation. It has been hypothesised that low levels of vitamin $D$ increase the risk of autoimmune disease. Considering that vitamin $D$ is implicated in immune regulation and autoimmunity, a question that arises is whether vitamin $D$ deficiency can lead to increased disease activity in axSpA. Through this narrative review of the literature the authors explore potential links between vitamin $\mathrm{D}$ and axSpA. This review highlights that larger and more methodologically robust prospective longitudinal studies are required to answer this key question. There was considerable heterogeneity between studies, including in the definition of vitamin $D$ deficiency, latitude where the study took place, and seasonal variation. Another clinically relevant aspect to address is whether correcting vitamin D deficiency leads to improved makers of disease activity in patients with ankylosing spondylitis. This may justify mandatory food fortification and specific supplementation programmes in countries at risk. For example, in Finland there is a low prevalence of vitamin D deficiency in the general population because of food fortification.

\section{INTRODUCTION}

Axial spondyloarthritis (axSpA) is a chronic inflammatory disease which predominantly involves the axial skeleton and sacroiliac joints; although, peripheral arthritis, enthesitis, and extra-articular features may also be present. The aetiology remains unknown but is thought to be immune driven. ${ }^{2}$ AxSpA can be classified into two subgroups: radiographic axSpA, commonly known as ankylosing spondylitis (AS) with defined structural changes in the sacroiliac joints as detected on plain radiography, and nonradiographic axSpA (nr-axSpA). AxSpA is diagnosed by the Assessment of SpondyloArthritis international Society (ASAS) classification criteria. 
Table 1: Vitamin D and disease activity in axial spondyloarthritis studies.

\begin{tabular}{|c|c|c|c|c|c|}
\hline $\begin{array}{l}\text { Author, year, } \\
\text { country } \\
\text { Study design } \\
\text { Season }\end{array}$ & Subjects & Controls & $\begin{array}{c}\text { Medications: } \\
\text { Vitamin D } \\
\text { supplement, NSAID, } \\
\text { DMARD, biologics }\end{array}$ & $\begin{array}{l}\text { Vitamin D } \\
\text { metabolite } \\
\text { Deficiency } \\
\text { definition }\end{array}$ & Results \\
\hline $\begin{array}{l}\text { Zhao et al., }{ }^{10} \\
2017, \text { UK } \\
\text { Cross-sectional } \\
\text { November } \\
2011-N o v e m b e r \\
2015\end{array}$ & $\begin{array}{c}\operatorname{axSpA} 235 \\
\text { patients (AS and } \\
\operatorname{axSpA)}\end{array}$ & None & $\begin{array}{c}\text { Vitamin D } \\
\text { supplement: included } \\
\text { (60 patients) } \\
\text { NSAID: } 163 \\
\text { DMARD: none } \\
\text { Biologics: } 74 \text { anti-TNF }\end{array}$ & $\begin{array}{l}25(\mathrm{OH}) \mathrm{D} \\
<30.0 \\
\mathrm{nmol} / \mathrm{L}\end{array}$ & $\begin{array}{c}\text { BASDAI score, ESR, and CRP } \\
\text { were higher in vitamin D } \\
\text { deficiency. }\end{array}$ \\
\hline $\begin{array}{l}\text { Yazmalar et al.,"1 } \\
\text { 2013, Turkey } \\
\text { Cohort } \\
\text { July- } \\
\text { September and } \\
\text { December- } \\
\text { February }\end{array}$ & $\begin{array}{l}72 \text { AS (Mod } \\
\text { NY criteria); } 28 \\
\text { completed the } \\
\text { study }\end{array}$ & $\begin{array}{l}71 \mathrm{RA}, 74 \\
\text { OA, } 70 \\
\text { healthy }\end{array}$ & $\begin{array}{c}\text { Vitamin D } \\
\text { supplement: included } \\
\text { NSAID: included } \\
\text { DMARD: included } \\
\text { Biologics: included }\end{array}$ & $\begin{array}{c}25(\mathrm{OH}) \mathrm{D} \\
\text { Not defined }\end{array}$ & $\begin{array}{c}\text { No difference between } \\
\text { groups for vitamin D levels } \\
\text { between seasons. BASDAl } \\
\text { scores differed between } \\
\text { seasons }(p<0.05) \text {. AS had } \\
\text { higher CRP levels but not } \\
\text { ESR levels. No association } \\
\text { between BASDAI score and } \\
\text { vitamin D. }\end{array}$ \\
\hline $\begin{array}{l}\text { Kolahi et al.,12 } \\
\text { 2019, Iran } \\
\text { Cross-sectional } \\
\text { March- } \\
\text { September } \\
2018\end{array}$ & $\begin{array}{l}86 \mathrm{SpA} \text { (AS 65, } \\
\text { undifferentiated } \\
\text { 14) (International } \\
\text { criteria) }\end{array}$ & $\begin{array}{l}117 \text { healthy, } \\
\text { age and sex- } \\
\text { matched }\end{array}$ & $\begin{array}{c}\text { Vitamin D } \\
\text { supplement: excluded } \\
\text { NSAID: not } \\
\text { mentioned } \\
\text { DMARD: not } \\
\text { mentioned } \\
\text { Biologics: not } \\
\text { mentioned }\end{array}$ & $\begin{array}{l}25(\mathrm{OH}) \mathrm{D} \\
<10.0 \\
\mathrm{nmol} / \mathrm{L}\end{array}$ & $\begin{array}{c}\text { Vitamin D was lower in SpA. } \\
\text { No correlation with BASDAI } \\
\text { score. }\end{array}$ \\
\hline $\begin{array}{l}\text { Hmamouchi } \\
\text { et al., }{ }^{13} 2013, \\
\text { Morocco } \\
\text { Cross-sectional } \\
\text { Summer }\end{array}$ & $\begin{array}{l}70 \text { AS (Mod NY } \\
\text { criteria) }\end{array}$ & $\begin{array}{l}140 \text { healthy } \\
<65 \text { years }\end{array}$ & $\begin{array}{c}\text { Vitamin D } \\
\text { supplement: excluded } \\
\text { NSAID: } 58 \\
\text { DMARD: none } \\
\text { Biologics: } 8 \text { anti-TNF }\end{array}$ & $\begin{array}{l}25(\mathrm{OH}) \mathrm{D} \\
<20.0 \\
\mathrm{nmol} / \mathrm{L}\end{array}$ & $\begin{array}{l}\text { Vitamin D was lower in AS } \\
\text { group. CRP was higher in } \\
\text { AS. Vitamin D negatively } \\
\text { correlated with BASDAI } \\
\text { score. }\end{array}$ \\
\hline $\begin{array}{l}\text { Kültür et al.,8 } \\
\text { 2019, Turkey } \\
\text { Cross-sectional } \\
\text { July 2016- } \\
\text { January } 2017\end{array}$ & $\begin{array}{c}62 \text { AS (Mod NY } \\
\text { criteria) }\end{array}$ & 32 healthy & $\begin{array}{l}\text { Vitamin D } \\
\text { supplement: not } \\
\text { mentioned } \\
\text { NSAID: included } \\
\text { DMARD: not } \\
\text { mentioned } \\
\text { Biologics: included }\end{array}$ & $\begin{array}{c}\text { SVDR } \\
\text { Not defined }\end{array}$ & $\begin{array}{l}\text { No difference between SVDR } \\
\text { levels between control and } \\
\text { AS groups. SVDR levels } \\
\text { were higher in AS patients } \\
\text { with a BASDAl score }>4, \\
\text { compared to controls and } \\
\text { inactive AS. No difference } \\
\text { between NSAID and anti-TNF } \\
\text { therapies. SVDR correlated } \\
\text { with ESR and CRP. }\end{array}$ \\
\hline $\begin{array}{l}\text { Koçyiğit, } \\
\text { Akyol, }{ }^{14} 2018, \\
\text { Turkey } \\
\text { Cross-sectional } \\
\text { March-May } \\
2018\end{array}$ & $\begin{array}{c}68 \text { AS (Mod NY } \\
\text { criteria) }\end{array}$ & 34 healthy & $\begin{array}{c}\text { Vitamin D } \\
\text { supplement: excluded } \\
\text { NSAID: } 36 \\
\text { DMARD: none } \\
\text { Biologics: } 32 \text { anti-TNF }\end{array}$ & $\begin{array}{c}25(\mathrm{OH}) \mathrm{D} \\
\text { Not defined }\end{array}$ & $\begin{array}{l}\text { Vitamin D was lower in AS } \\
\text { group. No difference in } \\
\text { vitamin D between treatment } \\
\text { groups. Vitamin D was not } \\
\text { associated with BASDAl } \\
\text { score, ASDAS-CRP, ESR, or } \\
\text { CRP. }\end{array}$ \\
\hline $\begin{array}{l}\text { Hmamouchi } \\
\text { et al.,15 2016, } \\
\text { France } \\
\text { Prospective } \\
\text { longitudinal } \\
\text { Four seasons }\end{array}$ & $\begin{array}{c}\text { Symptoms } \\
\text { suggestive of } \\
\text { AxSpA. (IBP } \\
\text { criteria, ASAS } \\
\text { classification); } \\
486\end{array}$ & $\begin{array}{l}\text { Healthy from } \\
2006-2007 \\
\text { data }\end{array}$ & $\begin{array}{l}\text { Vitamin D } \\
\text { supplement: not } \\
\text { mentioned } \\
\text { NSAID: included } \\
\text { DMARD: not } \\
\text { mentioned } \\
\text { Biologics: included }\end{array}$ & $\begin{array}{l}25(\mathrm{OH}) \mathrm{D} \\
<50.0 \\
\mathrm{nmol} / \mathrm{L}\end{array}$ & $\begin{array}{l}\text { Vitamin D was lower in DESIR } \\
\text { cohort and between winter } \\
\text { to spring. Those with vitamin } \\
\text { D deficiency at baseline had } \\
\text { higher BASDAl scores, but } \\
\text { ASDAS was not statistically } \\
\text { significant. }\end{array}$ \\
\hline
\end{tabular}


Table 1 continued.

\begin{tabular}{|c|c|c|c|c|c|}
\hline $\begin{array}{l}\text { Author, year, } \\
\text { country } \\
\text { Study design } \\
\text { Season }\end{array}$ & Subjects & Controls & $\begin{array}{c}\text { Medications: } \\
\text { Vitamin D } \\
\text { supplement, NSAID, } \\
\text { DMARD, biologics }\end{array}$ & $\begin{array}{l}\text { Vitamin D } \\
\text { metabolite } \\
\text { Deficiency } \\
\text { definition }\end{array}$ & Results \\
\hline $\begin{array}{l}\text { Lange et al., }{ }^{16} \\
\text { 2001, Germany } \\
\text { Cross-sectional } \\
\text { May-August } \\
1998\end{array}$ & $\begin{array}{c}70 \text { AS (Mod NY } \\
\text { criteria) }\end{array}$ & 45 healthy & $\begin{array}{c}\text { Vitamin D } \\
\text { supplement: not } \\
\text { mentioned } \\
\text { NSAID: } 58 \\
\text { DMARD: } 7 \text { MTX, } 5 \text { SSZ } \\
\text { Biologics: not } \\
\text { mentioned }\end{array}$ & $\begin{array}{c}1,25(\mathrm{OH})_{2} \mathrm{D} \\
\text { and } 25(\mathrm{OH}) \\
\mathrm{D} \\
<6.0 \mathrm{ng} / \mathrm{mL}\end{array}$ & $\begin{array}{c}\text { AS had higher ESR and } \\
\text { CRP and lower } 1,25(\mathrm{OH})_{2} \mathrm{D} \\
\text { than controls. 1,25(OH) } \mathrm{D} \\
\text { negatively correlated with } \\
\text { disease activity (ESR, CRP, } \\
\text { and BASDAl score). }\end{array}$ \\
\hline $\begin{array}{l}\text { Žagar et al.,17} \\
\text { 2019, Croatia } \\
\text { Cross-sectional } \\
\text { June } 2015-\text { April } \\
2016\end{array}$ & $\begin{array}{c}150 \text { AS (ASAS } \\
\text { criteria) }\end{array}$ & None & $\begin{array}{c}\text { Vitamin D } \\
\text { supplement: none } \\
\text { before study } \\
\text { NSAID: not } \\
\text { mentioned } \\
\text { DMARD: } 53 \text { MTX/ } \\
\text { SSZ/LEF. } \\
\text { Biologics: } 31 \text { anti-TNF }\end{array}$ & $\begin{array}{l}25(\mathrm{OH}) \mathrm{D} \\
<50.0 \\
\mathrm{nmol} / \mathrm{L}\end{array}$ & $\begin{array}{c}\text { No correlation with } \\
\text { BASDAl score, ESR, or } \\
\text { CRP and vitamin D. No } \\
\text { difference in mean vitamin } \\
\text { D concentration through } \\
\text { seasons. }\end{array}$ \\
\hline $\begin{array}{l}\text { Üstün, } \\
\text { Turhanoğlu, }{ }^{18} \\
\text { 2014, Turkey } \\
\text { Cross-sectional } \\
\text { Winter }\end{array}$ & $\begin{array}{c}75 \text { AS (criteria } \\
\text { not mentioned) }\end{array}$ & 35 healthy & $\begin{array}{l}\text { Vitamin D } \\
\text { supplement: not } \\
\text { mentioned } \\
\text { NSAID: not } \\
\text { mentioned } \\
\text { DMARD: not } \\
\text { mentioned } \\
\text { Biologics: not } \\
\text { mentioned }\end{array}$ & $\begin{array}{c}25(\mathrm{OH}) \mathrm{D} \\
\text { Not defined }\end{array}$ & $\begin{array}{c}\text { Vitamin D was low in both } \\
\text { groups. No correlation } \\
\text { between vitamin D and } \\
\text { BASDAl score. }\end{array}$ \\
\hline $\begin{array}{l}\text { Erten et al., }{ }^{19} \\
\text { 2012, Turkey } \\
\text { Cross-sectional } \\
\text { Winter: } \\
\text { December- } \\
\text { March }\end{array}$ & $\begin{array}{l}48 \text { AS (Mod } \\
\text { NY criteria), } 113 \\
\text { undifferentiated } \\
\text { SpA (ESSG } \\
\text { criteria) }\end{array}$ & 92 healthy & $\begin{array}{c}\text { Vitamin D } \\
\text { supplement: not } \\
\text { mentioned NSAID: } \\
\text { included } \\
\text { DMARD: not } \\
\text { mentioned Biologics: } \\
\text { not mentioned } \\
\end{array}$ & $\begin{array}{l}25(\mathrm{OH}) \mathrm{D} \\
<10.0 \\
\mathrm{nmol} / \mathrm{L}\end{array}$ & $\begin{array}{l}\text { Vitamin D was lower in AS. } \\
\text { Vitamin D inversely related } \\
\text { to ESR and CRP in AS group } \\
\text { only. No correlation between } \\
\text { vitamin D and BASDAI score. }\end{array}$ \\
\hline $\begin{array}{l}\text { Durmus et al., }{ }^{19} \\
\text { 2012, Turkey } \\
\text { Cross-sectional } \\
\text { Unknown }\end{array}$ & $\begin{array}{l}99 \text { AS (Mod NY } \\
\text { criteria) }\end{array}$ & 42 healthy & $\begin{array}{c}\text { Vitamin D } \\
\text { supplement: excluded } \\
\text { NSAID: not } \\
\text { mentioned } \\
\text { DMARD: not } \\
\text { mentioned } \\
\text { Biologics: not } \\
\text { mentioned }\end{array}$ & $\begin{array}{l}25(\mathrm{OH}) \mathrm{D} \\
<2 \mathrm{O} .0 \\
\mathrm{nmol} / \mathrm{L}\end{array}$ & $\begin{array}{c}\text { Vitamin D was lower in } \\
\text { AS, but not statistically } \\
\text { significant. ESR, CRP, and } \\
\text { BASDAI score were higher } \\
\text { in vitamin D deficiency } \\
\text { subgroup. BASDAl score, } \\
\text { ESR, and CRP inversely } \\
\text { correlated with vitamin D } \\
\text { levels. }\end{array}$ \\
\hline $\begin{array}{l}\text { Klingberg et } \\
\text { al.,20 2016, } \\
\text { Sweden } \\
\text { Cross-sectional } \\
\text { February-April } \\
2009\end{array}$ & $\begin{array}{c}203 \text { AS (Mod NY } \\
\text { criteria) }\end{array}$ & 120 healthy & $\begin{array}{c}\text { Vitamin D } \\
\text { supplement: included } \\
\text { (42 patients) } \\
\text { NSAID: included } \\
\text { DMARD: included } \\
\text { Biologics: included }\end{array}$ & $\begin{array}{l}25(\mathrm{OH}) \mathrm{D} \\
<25 . \mathrm{O} \\
\mathrm{nmol} / \mathrm{L}\end{array}$ & $\begin{array}{l}\text { No difference in vitamin D } \\
\text { levels between groups once } \\
\text { those taking supplements } \\
\text { were excluded. There was no } \\
\text { correlation between vitamin } \\
\text { D and ASDAS-CRP, BASDAI } \\
\text { score, ESR, or CRP. No } \\
\text { difference in vitamin D with } \\
\text { those taking NSAID versus } \\
\text { anti-TNF versus DMARD. }\end{array}$ \\
\hline $\begin{array}{l}\text { Mermerci } \\
\text { Bașkan et al., } \\
\text { 2010, Turkey } \\
\text { Cross-sectional } \\
\text { Unknown }\end{array}$ & $\begin{array}{l}100 \text { AS (Mod NY } \\
\text { criteria) }\end{array}$ & 58 healthy & $\begin{array}{c}\text { Vitamin D } \\
\text { supplement: not } \\
\text { mentioned } \\
\text { NSAID: } 100 \\
\text { DMARD: } 83 \text { SSZ/MTX } \\
\text { Biologics: } 8 \text { anti-TNF }\end{array}$ & $\begin{array}{l}25(\mathrm{OH}) \mathrm{D} \\
<20.0 \\
\mathrm{nmol} / \mathrm{L}\end{array}$ & $\begin{array}{l}\text { Vitamin D was lower in AS. } \\
\text { Negative correlation with } \\
\text { vitamin D and ESR/CRP, but } \\
\text { not statistically significant. No } \\
\text { correlation between vitamin } \\
\text { D and BASDAI score. }\end{array}$ \\
\hline
\end{tabular}


Table 1 continued.

\begin{tabular}{|c|c|c|c|c|c|}
\hline $\begin{array}{l}\text { Author, year, } \\
\text { country } \\
\text { Study design } \\
\text { Season }\end{array}$ & Subjects & Controls & $\begin{array}{c}\text { Medications: } \\
\text { Vitamin D } \\
\text { supplement, NSAID, } \\
\text { DMARD, biologics }\end{array}$ & $\begin{array}{l}\text { Vitamin D } \\
\text { metabolite } \\
\text { Deficiency } \\
\text { definition }\end{array}$ & Results \\
\hline $\begin{array}{l}\text { Braun- } \\
\text { Moscovici et } \\
\text { al.,22 2011, Israel } \\
\text { Cross-sectional } \\
\text { Winter and } \\
\text { summer }\end{array}$ & $\begin{array}{c}14 \text { AS (Mod NY } \\
\text { criteria) }\end{array}$ & $\begin{array}{c}85 \text { RA, } 22 \\
\text { PsA }\end{array}$ & $\begin{array}{c}\text { Vitamin D } \\
\text { supplement: included } \\
\text { NSAID: not } \\
\text { mentioned } \\
\text { DMARD: included } \\
\text { Biologics: included }\end{array}$ & $\begin{array}{l}25(\mathrm{OH}) \mathrm{D} \\
<12.0 \mathrm{ng} / \\
\mathrm{mL}=4.8 \\
\mathrm{nmol} / \mathrm{L}\end{array}$ & $\begin{array}{c}\text { No difference with vitamin D } \\
\text { and season. No correlation } \\
\text { between vitamin D and } \\
\text { BASDAI score. }\end{array}$ \\
\hline $\begin{array}{l}\text { Lange et al., }{ }^{23} \\
2005, \text { Germany } \\
\text { Cross-sectional } \\
\text { Summer }\end{array}$ & $\begin{array}{c}58 \text { AS (Mod NY } \\
\text { criteria) }\end{array}$ & 58 healthy & $\begin{array}{c}\text { Vitamin D } \\
\text { supplement: not } \\
\text { mentioned } \\
\text { NSAID: } 45 \\
\text { DMARD: } 12 \text { MTX/SSZ } \\
\text { Biologics: not } \\
\text { mentioned }\end{array}$ & $\begin{array}{l}1,25(\mathrm{OH}) \mathrm{D} \\
<20.0 \mathrm{pg} / \\
\mathrm{mL}\end{array}$ & $\begin{array}{l}1,25(\mathrm{OH})_{2} \mathrm{D} \text { was lower in AS } \\
\text { group, which negatively } \\
\text { correlated with BASDAI } \\
\text { score, ESR, and CRP. }\end{array}$ \\
\hline $\begin{array}{l}\text { Guła et al., }{ }^{24} \\
\text { 2018, Poland } \\
\text { Cross-sectional } \\
\text { Seasonal } \\
\text { variation }\end{array}$ & $\begin{array}{c}11 \text { axSpA (ASAS } \\
\text { criteria), } 29 \\
\text { AS (Mod NY } \\
\text { criteria) }\end{array}$ & $\begin{array}{l}12 \text { PsA, } 11 \\
\text { perSpA }\end{array}$ & $\begin{array}{l}\text { Vitamin D } \\
\text { supplement: included } \\
\text { NSAID: included } \\
\text { DMARD: included } \\
\text { Biologics: included }\end{array}$ & $\begin{array}{l}25(\mathrm{OH}) \mathrm{D} \\
<30.0 \mathrm{ng} / \\
\mathrm{mL}=12.0 \\
\mathrm{nmol} / \mathrm{L}\end{array}$ & $\begin{array}{l}\text { No difference in vitamin D } \\
\text { levels between axSpA versus } \\
\text { perSpA. No association with } \\
\text { vitamin D deficiency and } \\
\text { BASDAI score, CRP, ESR, } \\
\text { or ASDAS. No difference } \\
\text { between NSAID or biologic } \\
\text { DMARD and vitamin } \\
\text { D deficiency. Positive } \\
\text { correlation between vitamin } \\
\text { D and ESR in axSpA only. }\end{array}$ \\
\hline $\begin{array}{l}\text { Ozkan et al., } \\
\text { 2017, Turkey } \\
\text { Prospective } \\
\text { controlled } \\
\text { July- } \\
\text { September and } \\
\text { December- } \\
\text { February }\end{array}$ & $\begin{array}{c}32 \text { AS (Mod NY } \\
\text { criteria) }\end{array}$ & $\begin{array}{l}25 \text { OA, } 25 \\
\text { fibromyalgia, } \\
25 \text { healthy }\end{array}$ & $\begin{array}{c}\text { Vitamin D } \\
\text { supplement: excluded } \\
\text { NSAID: not } \\
\text { mentioned } \\
\text { DMARD: not } \\
\text { mentioned } \\
\text { Biologics: not } \\
\text { mentioned }\end{array}$ & $\begin{array}{c}25(\mathrm{OH}) \mathrm{D} \\
\text { Not defined }\end{array}$ & $\begin{array}{l}\text { No difference in BASDAI } \\
\text { score in AS patients between } \\
\text { summer and winter, and no } \\
\text { association with vitamin D. } \\
\text { Vitamin D was lowest in AS } \\
\text { winter group but not summer. }\end{array}$ \\
\hline $\begin{array}{l}\text { Yagiz et al.., }{ }^{26} \\
\text { 2015, Turkey } \\
\text { Retrospective } \\
\text { Winter-Spring }\end{array}$ & $\begin{array}{l}100 \text { AS (Mod NY } \\
\text { criteria) }\end{array}$ & $\begin{array}{c}92 \text { RA, } 62 \\
\text { healthy }\end{array}$ & $\begin{array}{c}\text { Vitamin D } \\
\text { supplement: not } \\
\text { mentioned } \\
\text { NSAID: included } \\
\text { DMARD: included } \\
\text { Biologics: } 29 \text { anti-TNF }\end{array}$ & $\begin{array}{l}25(\mathrm{OH}) \mathrm{D} \\
<20.0 \mathrm{ng} / \\
\mathrm{mL}=8.0 \\
\mathrm{nmol} / \mathrm{L}\end{array}$ & $\begin{array}{l}\text { Vitamin D deficiency was } \\
\text { common in all groups. } \\
\text { Vitamin D levels were not } \\
\text { different in AS patients in a } \\
\text { subgroup of low versus high } \\
\text { disease activity. Treatment } \\
\text { groups had no statistically } \\
\text { significant correlation with } \\
\text { vitamin D level. In AS, vitamin } \\
\text { D did not correlate with } \\
\text { BASDAl score, ESR, or CRP. }\end{array}$ \\
\hline $\begin{array}{l}\text { Fernandes } \\
\text { et al.,27 } 2018, \\
\text { Global } \\
\text { Cross-sectional } \\
\text { Four seasons }\end{array}$ & $\begin{array}{c}\text { 1,030 SpA- } \\
\text { (ASAS criteria) }\end{array}$ & None & $\begin{array}{c}\text { Vitamin D } \\
\text { supplement: excluded } \\
\text { NSAID: } 919 \\
\text { DMARD: } 814 \\
\text { Biologics: } 499 \text { anti- } \\
\text { TNF }\end{array}$ & $\begin{array}{l}25(\mathrm{OH}) \mathrm{D} \\
<20.0 \\
\mathrm{nmol} / \mathrm{L}\end{array}$ & $\begin{array}{l}\text { Vitamin D deficiency was } \\
\text { associated with higher } \\
\text { BASDAI and ASDAS } \\
\text { scores, although observed } \\
\text { differences were small. } \\
\text { Vitamin D deficiency was } \\
\text { associated with radiographic } \\
\text { sacroiliitis but there was no } \\
\text { difference in MRI sacroiliitis } \\
\text { between the two groups. }\end{array}$ \\
\hline
\end{tabular}

AS: ankylosing spondylitis; ASAS criteria: Assessment of SpondyloArthritis international Society criteria; axSpA: axial spondyloarthritis; BASDAI: Bath Ankylosing Spondylitis Disease Activity Index; CRP: C-reactive protein; DESIR: devenir des spondyloarthrites indifférenciées récentes; DMARD: disease-modifying antirheumatic drug; ESR: erythrocyte sedimentation rate; ESSG: European Spondylitis Study Group; IBP: inflammatory back pain; LEF: leflunomide; Mod NY criteria: modified New York criteria for ankylosing spondylitis; MTX: methotrexate; NSAID: nonsteroidal anti-inflammatory drug; OA: osteoarthritis; perSpA: peripheral spondyloarthritis; PsA: psoriatic arthritis; RA: rheumatoid arthritis; SpA: spondyloarthritis; SSZ: sulfasalazine; SVDR: serum vitamin D receptor. 
Treatments recommended for both conditions include physiotherapy, nonsteroidal antiinflammatory drugs (NSAID), disease-modifying antirheumatic drugs (DMARD) including methotrexate and sulfasalazine for peripheral arthritis, and biologic therapies including antiTNF and IL-17A.

Vitamin $D$ has been a focus for research in numerous autoimmune conditions including multiple sclerosis and rheumatoid arthritis. ${ }^{3}$ Vitamin D2 (ergocalciferol) is derived from dietary sources, whilst vitamin D3 (colecalciferol) is primarily synthesised in the epidermis through exposure to ultraviolet B (UVB) light. Both vitamins D2 and D3 are converted in the liver and subsequently hydroxylated in the kidneys to form 1,25-dihydroxycholecalciferol $\left(1,25(\mathrm{OH})_{2} \mathrm{D}\right)$, the active metabolite of vitamin $\mathrm{D}$. The role of vitamin D was previously considered solely for calcium regulation and skeletal homeostasis, but now its role in the immune system is of particular interest. For instance, $1,25(\mathrm{OH})_{2} \mathrm{D}$ has inhibitory effects on dendritic cells, promoting monocyteto-macrophage differentiation and producing immunosuppressant cytokines. ${ }^{4} \quad 1,25(\mathrm{OH})_{2} \mathrm{D}$ also promotes increased phagocytic activity of macrophages. Its effect on the acquired immune system includes reducing proinflammatory T-helper 1 and Th17 cell activity, limiting the production of proinflammatory cytokines IL-1, TNF-a, IL-6, and IL-17A. ${ }^{5}$ Furthermore, $1,25(\mathrm{OH})_{2} \mathrm{D}$ acts on $\mathrm{T}$ regulatory cells and Th2 responses, raising $\mathrm{IL}-10$, an anti-inflammatory cytokine. ${ }^{5}$ Vitamin $D$ binds to a nuclear vitamin $D$ receptor (VDR) to either activate or inhibit target genes. ${ }^{6}$ It may act to regulate NF-kB activation which is increased in AS.7 This is important for the expression of adhesion molecules and other proinflammatory genes. ${ }^{8}$

It has been hypothesised that low levels of vitamin $D$ increase the risk of autoimmune disease. ${ }^{9}$ Considering vitamin $D$ is implicated in immune regulation and autoimmunity, a question that arises is whether vitamin $D$ deficiency can lead to increased disease activity in axSpA. The objective of this narrative review of the literature is to explore the association between vitamin $D$ and disease activity in axSpA. A search of the current literature was performed on Medline, Embase, and Cochrane using the medical subject heading terms "ankylosing spondylitis," "axial spondyloarthropathy," and "vitamin
D." References from review papers were also reviewed for relevance.

\section{HOW COMMON IS VITAMIN D DEFICIENCY IN AXSPA?}

Several studies highlighted that vitamin D deficiency is more frequent in patients with AS than in healthy controls (Table 1). ${ }^{10-27}$ In a study from Israel, vitamin $D$ levels were shown to be lower in patients with AS than in patients with rheumatoid arthritis and psoriatic arthritis. ${ }^{22}$ However, the sample size was small, with only 14 patients with AS included. Frequency of vitamin $D$ deficiency in the study was higher in those of Arabic ethnicity (76.7\%) compared to individuals of Jewish ethnicity (23.0\%). ${ }^{22}$ However, in one of the largest studies examining 203 AS patients from Sweden, no difference in vitamin $D$ levels was found between AS patients and controls. It must be noted that the AS group were older, had higher BMI, had a higher prevalence of tobacco smoking, and were more likely to take vitamin D supplementation than the control group. When patients taking vitamin D supplements were excluded from the results, there was no difference in vitamin $D$ levels between the two groups. ${ }^{20}$

Studies focussing on the association between vitamin D levels and disease activity in AS were predominantly conducted in Europe or in countries bordering the Mediterranean Sea, with the majority taking place in Turkey where vitamin $D$ deficiency is common. ${ }^{28} \mathrm{~A}$ global study (ASAS-COMOSPA) that included patients from 18 countries, with $82.3 \%$ located in a latitude greater than $37^{\circ}$ North, has shown interesting results. ${ }^{27}$ Of the 1,030 patients with spondyloarthritis as defined by the ASAS criteria, $51.2 \%$ were found to be deficient in vitamin D. ${ }^{27}$ Single-centre studies in North or South America, Australasia, or Asia are lacking.

Vitamin D deficiency is likely to be common in the UK, since one-third of UK adults who had been tested for vitamin $\mathrm{D}$ in primary care were found to be deficient. ${ }^{29}$ Rates of vitamin $D$ deficiency are also higher in ethnic minority populations in the UK. ${ }^{29}$ Global prevalence is difficult to ascertain because of a lack of data, especially from Africa and South America, although an estimated 1 billion people have a vitamin D deficiency. ${ }^{30,31}$ Vitamin D deficiency is especially widespread in 
the Middle East. ${ }^{32}$ Furthermore, Finland, a country with low levels of sunlight, has implemented a national health promotion programme regarding vitamin $D$ supplementation and fortification of milk and dairy products. ${ }^{33}$ This has resulted in increased vitamin $D$ intake and higher vitamin D concentrations. ${ }^{34}$

\section{SEASONAL VARIATION ON THE IMPACT OF VITAMIN D}

There was significant seasonal variation between studies, with the majority occurring in either the winter or summer. Several studies collected data over a number of seasons. In two studies in Turkey, vitamin D was low in the AS group and control groups over the winter period..$^{18,26}$ In a Swedish study, sunlight was not found to be a factor in their results because the study occurred over winter months when UVB levels were too low for synthesis of vitamin D. ${ }^{20}$ In comparison, the summer studies found that vitamin $D$ levels remained lower in AS groups than in controls. This included the two studies which measured the active metabolite $1,25(\mathrm{OH})_{2} \mathrm{D}^{16,23}$ Widespread deficiency of vitamin $\mathrm{D}$ is common throughout the summer, which is interesting because cutaneous synthesis via exposure to UV light is the main source for vitamin D. Five to 10 minutes of sun exposure three times per week is sufficient to guarantee vitamin D supply. ${ }^{35}$ People with darker skin absorb more UVB in the melanin of their skin than people with fair skin, and therefore require more sun exposure to produce the same amount of vitamin D. ${ }^{36,37}$ Only $10 \%$ of vitamin $\mathrm{D}$ is provided by the diet. ${ }^{22}$

\section{MEASUREMENT OF VITAMIN D LEVELS}

Several studies report on actual 25-hydroxycholecalciferol, or 25(OH)D, levels. However, there were considerable differences in the cut-off values to define vitamin $D$ deficiency. Global consensus to define vitamin D deficiency is lacking. The Endocrine Society definition states a value $<50.0 \mathrm{nmol} / \mathrm{L}$, whereas the Institute of Medicine (IOM) committee disagrees with this definition, recommending $<30.0 \mathrm{nmol} / \mathrm{L}$ to define deficiency, ${ }^{38}$ and states that a level $>40.0 \mathrm{nmol} / \mathrm{L}$ meets the level required for approximately half the population to have good bone health. ${ }^{39}$ The range for vitamin $D$ deficiency in the studies evaluated was from $4.8 \mathrm{nmol} / \mathrm{L}$ to $50.0 \mathrm{nmol} / \mathrm{L}$, and the median was $20.0 \mathrm{nmol} / \mathrm{L}$. Having a large range makes comparisons between studies difficult, and cut-off values may lead to differences in the interpretation of results. Two studies by Lange et al. ${ }^{16,23}$ measured the active metabolite 1,25(OH)2D, which has a short half-life (approximately 4 hours), compared to $25(\mathrm{OH}) \mathrm{D}$ which has a half-life of $2-3$ weeks. ${ }^{40}$ $1,25(\mathrm{OH})_{2} \mathrm{D}$ is also influenced by the VDR, vitamin D-binding protein, and 1-a-hydroxylase, so requires cautious interpretation. ${ }^{41}$ Further reasons why the concentration of $1,25(\mathrm{OH})_{2} \mathrm{D}$ cannot be utilised as a marker of vitamin $D$ status are that low concentrations of the final metabolite are detected in the serum, and that a very small amount of $25(\mathrm{OH}) \mathrm{D}$ can be converted to $1,25(\mathrm{OH})_{2} \mathrm{D}$ which provide a false idea of sufficiency. ${ }^{39}$ It is only when $25(\mathrm{OH}) \mathrm{D}$ falls below $10.0 \mathrm{nmol} / \mathrm{L}$ that $1,25(\mathrm{OH})_{2} \mathrm{D}$ decreases. ${ }^{42}$

One novel study measured serum VDR (SVDR), where vitamin $D$ binds to activate or inhibit the target genes which play a role in immunological regulation. Polymorphisms of VDR-encoded genes may play a role in the pathogenesis, disease activation, and clinical features of $\mathrm{AS}^{8}$ These genes could represent a potential target for modifying disease expression and behaviour.

\section{DISEASE ACTIVITY AND VITAMIN D DEFICIENCY}

No clear association has been identified between disease activity and vitamin D deficiency. Studies that found a negative correlation between vitamin D and Bath Ankylosing Spondylitis Disease Activity Index (BASDAI) include one study that recruited male patients only. ${ }^{13}$ Raised inflammatory markers, including erythrocyte sedimentation rate (ESR) and C-reactive protein (CRP), and BASDAI scores have been shown to be higher in AS patients with vitamin $D$ deficiency compared to AS patients with normal vitamin $D$ levels. ${ }^{19}$ Serum $1,25(\mathrm{OH})_{2} \mathrm{D}$, the active metabolite, is also negatively correlated with ESR, CRP, and BASDAl scores in patients with $A_{S}{ }^{16,23}$ In the DESIR cohort, a prospective observational study, vitamin D deficiency was associated with higher BASDAl and Ankylosing Spondylitis Disease Activity (ASDAS) scores, although ASDAS scores were not statistically significant. $^{15}$ Vitamin D deficiency was also 
associated with radiological sacroiliitis at baseline assessment. ${ }^{15}$ The inclusion criteria for this study, however, were patients with inflammatory back pain suggestive of spondyloarthritis who were subsequently classified according to the ASAS criteria. Serum VDR levels were positively correlated with BASDAI, CRP, and ESR. ${ }^{8}$ In the ASAS-COMOSPA study, patients with vitamin $D$ deficiency had higher BASDAI and ASDAS scores than those with normal vitamin D levels, although the observed differences were small. ${ }^{27}$ Radiographic sacroiliitis was also more prevalent in the vitamin D-deficient group, but there was no difference in MRI sacroiliitis between the two groups. Two limitations to this study were that serum vitamin $D$ levels were derived from a variety of laboratory methods, and 239 patients with psoriasis and 53 patients with inflammatory bowel disease were included in the study. ${ }^{27}$

Several studies found no association between vitamin $D$ deficiency and increased disease activity as measured by BASDAI. ${ }^{11,12,14}$ There was also no association with vitamin $D$ level and ASDAS-CRP. ${ }^{20}$ There was a positive correlation between vitamin $D$ levels and ESR in patients with axSpA, but no association with vitamin $D$ deficiency and BASDAI, CRP, and ASDAS. The authors could not explain this result. ${ }^{24}$

\section{Evidence from Systematic Reviews and Meta-Analyses}

A meta-analysis by Cai et al. $^{3}$ found that higher levels of disease activity were present in patients with low vitamin D levels. Vitamin D deficiency was also associated with AS susceptibility. However, the heterogeneity of the studies $\left(1^{2}=90 \%\right)$ makes comparisons between studies difficult. Only eight studies were included in the meta-analysis and most were from Chinese databases, which were not included in the present narrative review. A systematic review by Zhao et al. ${ }^{41}$ in 2014 found that vitamin $D$ was lower in patients with $A S$, but there were insufficient published data to support an immunomodulatory role for vitamin $D$ in $A S$. No studies included in the systematic review were prospective longitudinal studies.

Another systematic review by Kriegel et al., ${ }^{43}$ which evaluated whether vitamin $D$ affects the risk of developing an autoimmune disease, concluded that cross-sectional data pointed to a potential role of vitamin $D$ in autoimmune disease prevention. Only four case-controlled studies for patients with AS were included, two of which measured the active metabolite $1,25(\mathrm{OH})_{2} \mathrm{D}$ which has its limitations as previously discussed. ${ }^{16,23}$ Another study by Mermerci Bașkan et al. ${ }^{21}$ found no association between vitamin $D$ and BASDAl, and a further study found a negative correlation between CRP and vitamin $D$ in a combined cohort of $A S$ and psoriatic arthritis patients. ${ }^{44}$

\section{VITAMIN D SUPPLEMENTATION}

In the studies evaluated, most did not mention in their methods if patients were taking vitamin D supplementation. Five studies ${ }^{10,11,20,22,24}$ included information on supplementation and seven studies ${ }^{12-14,17,19,25,27}$ excluded vitamin $D$ supplementation. No difference in disease activity, as measured by BASDAI, ASDAS, CRP, and ESR, was found in patients with $A S$ and $n r-a x S p A$ once adjusted for vitamin D supplementation. ${ }^{24}$ Comparisons between AS and nr-axSpA as subgroups were not performed. Dietary intake of vitamin $D$ included fortified foods and was not taken into consideration in all studies. This was unlike a prospective controlled study of 40 patients with AS who had disease activity measured in the summer and winter. ${ }^{25}$ Patients taking calcium and vitamin D supplements were excluded from the study. There were no differences between dietary habits of patients with AS versus controls who had either osteoarthritis or fibromyalgia. However, the results do not include these data, and the methodology does not explain how dietary information was obtained and classified. Mean BASDAl value in the AS group did not show any significant difference between summer and winter, and there was no correlation between vitamin D and BASDAI in both seasons.

\section{THE ROLE OF DISEASE-MODIFYING ANTIRHEUMATIC DRUG THERAPIES ON VITAMIN D}

Studies generally show no statistically significant correlations between vitamin $D$ deficiency and anti-TNF therapy or DMARD. ${ }^{14,20}$ Patients treated with anti-TNF had lower BASDAI scores but vitamin $D$ levels were similar to those treated with 
DMARD. ${ }^{22}$ When SVDR levels were measured, a significant difference was found between patients taking NSAID versus anti-TNF biologic therapy. ${ }^{8}$ Anti-TNF therapy may suppress SVDR. In addition, SVDR levels of the AS group treated with NSAID were elevated compared to the control group. ${ }^{8}$

\section{KEY LEARNING POINTS}

Studies that focussed on vitamin D levels and disease activity in AS demonstrate considerable heterogeneity, including the definition of vitamin D deficiency, latitude where the study took place, and seasonal variation. Disease duration and severity of disease were often not taken into consideration which may implicate the findings to date. Sample size for a number of the studies was small, which is another important limitation. This makes the identification of causative links between vitamin D and disease activity difficult.

Vitamin D levels were often lower in patients with AS compared to controls, although in a large proportion of the studies vitamin D levels were low in both groups. Furthermore, patients with active disease are likely to be less mobile and subsequently are less likely to receive sun exposure. It is hypothesised that autoimmune disease incidence is associated with latitude. This may be explained by genetics, diet, infection, or exposure to UVB. In the studies evaluated, most occurred between the latitude $30-40^{\circ}$, which are associated with good levels of sunlight all year round. Patients from Morocco and Turkey often had low vitamin $D$ levels, which is likely caused by a combination of genetic, dietary, and clothing attire factors. In a Swedish study, sunlight was not a factor in their results because the study occurred over winter when UVB levels were too low for synthesis of vitamin $D,{ }^{20}$ which again suggests that genetic and dietary factors play an important role in influencing vitamin D levels. None of the studies provided evidence that the incidence for AS may be higher in countries with widespread vitamin $D$ deficiency compared to those without.

The greatest challenge in robustly determining if vitamin $D$ deficiency is associated with increased disease activity was the lack of prospective longitudinal studies. To date, only two of the studies are prospective longitudinal studies. One included only 32 patients with AS, but found no association between vitamin D levels and BASDAI scores, with no change in BASDAI score between winter and summer. ${ }^{25}$ The other prospective longitudinal study included patients presenting with inflammatory back pain suggestive of axSpA. Patients were subdivided into three groups: those who met ASAS criteria with imaging changes, those who met ASAS criteria with clinical parameters, and those who did not fulfil ASAS criteria. The modified New York criteria were not included in this study. The main finding was of a higher prevalence of vitamin D deficiency in spondyloarthritis at the onset of disease, which may correlate with more active and severe disease. This was supported by findings of greater prevalence of baseline radiological sacroiliitis in those with vitamin D deficiency. The level of vitamin D was negatively correlated with BASDAI and ASDAS score. ${ }^{15}$ Cross-sectional studies often only measured a 'snapshot' measurement of vitamin D, introducing bias and unexplained variability when level of sunlight exposure, dietary intake, and control for seasonal variation was poor.

A limitation in the disease activity reported in the studies is that patients often have normal serum inflammatory markers despite evidence for bone marrow oedema on MRI. Furthermore, vitamin D deficiency in healthy populations can manifest as arthralgia, and BASDAI scores in patients with vitamin $D$ deficiency may be higher as a result. The same applies to patients with secondary fibromyalgia, which has a high prevalence in AS. Fibromyalgia was not mentioned as an exclusion criterion in any of the studies. A more accurate assessment for disease activity would incorporate spinal imaging with BASDAI measurements.

\section{CONCLUSION}

In summary, larger and more methodologically robust prospective longitudinal studies are required to determine whether vitamin $D$ is related to disease activity. Another clinically relevant aspect to address is whether correcting vitamin $D$ deficiency leads to improved makers of disease activity in patients with AS. This may justify mandatory food fortification and specific supplementation programmes in countries at risk. 


\section{References}

1. Braun J. Axial spondyloarthritis including ankylosing spondylitis. Rheumatology (Oxford). 2018;57(Suppl 6):vi13.

2. de Koning A et al. Pathophysiology of axial spondyloarthritis: consensus and controversies. Eur J Clin Invest. 2018;48(5):e12913.

3. Rudwaleit $M$ et al. The development of assessment of spondyloarthritis international society classification criteria for axial spondyloarthritis (part II): validation and final selection. Ann Rheum Dis. 2009;68(6):777-83.

4. Cai $G$ et al. Vitamin D in ankylosing spondylitis: review and meta-analysis. Clin Chim Acta. 2015;438:316-22.

5. Helming $L$ et al. 1alpha,25Dihydroxyvitamin D3 is a potent suppressor of interferon gammamediated macrophage activation. Blood. 2005;106(13):4351-8.

6. Crotti C et al. Vitamin D and spondyloarthritis: review of the literature. Open Rheumatol $J$ 2018;12(Suppl 1, M3):214-25.

7. Wu S, Sun J. Vitamin D, vitamin D receptor, and macroautophagy in inflammation and infection. Discov Med. 2011;11(59):325-35.

8. Sun J et al. Increased NF-kappaB activity in fibroblasts lacking the vitamin D receptor. Am J Physiol Endocrinol Metab. 2006;291(2):E31522.

9. Kültür $T$ et al. The relationship of serum vitamin $D$ receptor levels with disease activity and clinical parameters in patients with ankylosing spondylitis. Turk J Phys Med Rehab. 2019;65(4):389-93.

10. Yang CY et al. The implication of vitamin D and autoimmunity: a comprehensive review. Clin Rev Allergy Immunol. 2013;45(2):217-26.

11. Zhao SZ et al. Vitamin D deficiency in axial spondyloarthritis is associated with higher disease activity. Arch Rheumatol. 2017;32(3):209-15.

12. Yazmalar L et al. Seasonal disease activity and serum vitamin D levels in rheumatoid arthritis, ankylosing spondylitis and osteoarthritis. 2013;13(1):47-55

13. Kolahi $\mathrm{S}$ et al. Does vitamin D deficiency contribute to higher disease activity in patients with spondyloarthritis? Immunol Lett. 2019;212:1-5.

14. Hmamouchi I et al. The relation between disease activity, vitamin $\mathrm{D}$ levels and bone mineral density in men patients with ankylosing spondylitis. Rheumatol Rep. 2013;5(1);e3.

15. Koçyiğit BF, Akyol A. Vitamin D levels in patients with ankylosing spondylitis: is it related to disease activity? Pak J Med Sci. 2018;34(5):1209-14.

16. Hmamouchi l et al. Vitamin D, disease activity and comorbidities in early spondyloarthritis. Clin Exp Rheumatol. 2016;34(3):396-403.

17. Lange $U$ et al. Relationship between disease activity and serum levels of vitamin D metabolites and parathyroid hormone in ankylosing spondylitis. Osteoporos Int. 2001;12(12):1031-5.

18. Žagar I et al. Correspondence of vitamin D status with functional scores and disease activity among Croatian patients with ankylosing spondylitis: a preliminary study. Psychiatr Danub. 2019;31(Suppl 1):105-11.

19. Erten $\mathrm{S}$ et al. Decreased plasma vitamin D levels in patients with undifferentiated spondyloarthritis and ankylosing spondylitis. Intern Med. 2013;52:339-344.

20. Üstün N, Turhanoğlu A. Vitamin D levels in patients with ankylosing spondylitis and its relationship with disease activity. Arch Rheumatol. 2014;29(4):321-2

21. Durmus B et al. Does vitamin D affect disease severity in patients with ankylosing spondylitis? Chin Med J (Engl). 2012;125(14):2511-5.

22. Klingberg $E$ et al. The vitamin $D$ status in ankylosing spondylitis in relation to intestinal inflammation, disease activity, and bone health: a cross sectional study. Osteoporos Int. 2016;27(6):2027-33.

23. Mermerci Bașkan B et al. The relation between osteoporosis and vitamin $\mathrm{D}$ levels and disease activity in ankylosing spondylitis. Rheumatol Int 2010;30(3):375-81.

24. Braun-Moscovici $Y$ et al. Vitamin D level: is it related to disease activity in inflammatory joint disease? Rheumatol Int. 2011;31(4):493-9.

25. Lange $U$ et al. Association of 1.25 vitamin D3 deficiency, disease activity and low bone mass in ankylosing spondylitis. Osteoporos Int 2005:16(12):1999-2004.

26. Guła Z et al. Vitamin D serum concentration is not related to the activity of spondyloarthritis preliminary study. Rheumatologia. 2018;56(6):388-91.

27. Ozkan A et al. Relationship between seasonal serum 25-hydroxy vitamin $D$ levels and disease activity in patients with ankylosing spondylitis, osteoarthritis, and fibromyalgia syndrome. J Clin Anal Med. 2017:8(6):523-8.

28. Yagiz AE et al. Association of vitamin $D$ with disease activity in rheumatoid arthritis and ankylosing spondylitis. J Clin Anal Med. 2015;6(4):486-9.
29. Fernandes S et al. Vitamin D status in spondyloarthritis: results of the ASAS-COMOSPA international study. Clin Exp Rheumatol. 2018;36(2):210-4

30. Satman I et al. Prevalence and correlates of vitamin D deficiency and associated factors in Turkish adults. Endocr Abstracts. 2013;32:P135.

31. Crowe FL et al. Trends in the incidence of testing for vitamin D deficiency in primary care in the UK: a retrospective analysis of The Health Improvement Network (THIN), 20052015. BMJ Open. 2019;9(6):e028355.

32. Holick MF. High prevalence of vitamin $D$ inadequacy and implications for health. Mayo Clin Proc. 2006;81(3):353-73

33. Gordon CM et al. Prevalence of vitamin D deficiency among healthy adolescents. Arch Pediatr Adolesc Med. 2004;158(6):531-7.

34. Palacios C, Gonzalez L. Is vitamin D deficiency a major global public health problem? J Steroid Biochem Mol Biol. 2014;144(Pt A):138-45.

35. Spiro A, Buttriss JL. Vitamin D: an overview of vitamin D status and intake in Europe. Nutr Bull. 2014;39(4):322-50

36. Raulio $\mathrm{S}$ et al. Successful nutrition policy: improvement of vitamin D intake and status in Finnish adults over the last decade. Euro J Public Health. 2017;27(2):268-73.

37. Holick MF. Vitamin D deficiency. N Engl J Med. 2007;357(3):266-81.

38. Nair R, Maseeh A. Vitamin D: The "sunshine" vitamin. J Pharmacol Pharmacother. 2012;3(2):118-26.

39. Rostand SG. Ultraviolet light may contribute to geographic and racial blood pressure differences Hypertension. 1997;30(2):150-6.

40. Cashman KD, Kiely M. Recommended dietary intakes for vitamin D: where do they come from, what do they achieve and how can we meet them? J Hum Nutr Diet. 2014;27(5):434-42.

41. Romagnoli E et al. Management of endocrine disease: value and limitations of assessing vitamin D nutritional status and advised levels of vitamin D supplementation. Eur J Endocrinol. 2013;169(4):R59-69.

42. Essouma M, Noubiap JJN. Are systematic screening for vitamin $\mathrm{D}$ deficiency and vitamin D supplementation currently feasible for ankylosing spondylitis patients? Int J Inflam. 2017;2017:7840150.

43. Zhao S et al. Systematic review of association between vitamin D levels and susceptibility and disease activity of ankylosing spondylitis. Rheumatology (Oxford). 2014:53(9):1595-603.

44. Fraser WD, Milan AM. Vitamin D 
assays: past and present debates, difficulties, and developments. Calcif Tissue Int. 2013;92(2):118-27.

45. Kriegel MA et al. Does vitamin D affect risk of developing autoimmune disease?: A systematic review. Semin Arthritis Rheum. 2011;40(6):512-31.

46. Teichmann $\mathrm{J}$ et al. Antibodies to human tissue transglutaminase and alterations of vitamin D metabolism in ankylosing spondylitis and psoriatic arthritis. Rheumatol Int. 2010;30(12):1559-63. 


\section{Never miss an update again.}

Join today for free to receive the latest publications, newsletters, and updates from a host of therapeutic areas. 